\title{
Research on Comparison of Postgraduate Training between Domestic and Foreign Maritime Academies
}

\author{
Guang Shao \\ Dalian Maritime University \\ Dalian, China
}

\begin{abstract}
The present research aims to find the deficiencies of postgraduate training in domestic maritime academies by analyzing training mode, curricula setting, experiment and practice, teaching form and administrative situation. Besides, based on training features and experiences of foreign maritime academies and practical environment and situation of domestic maritime academics, the research proposes improved measures on postgraduate training of maritime academics.
\end{abstract}

Keywords-postgraduate; maritime academics; training mode; comparative analysis

\section{INTRODUCTION}

With the rapid development of China's Higher Education, more and more undergraduates choose to pursue postgraduate education after they graduate. However, compared to developed countries, China's postgraduate education needs to improve in various aspects. The author will provide his point of view on this issue based on a basic research.

\section{CURRENT Situation OF Postgraduate Training OF DOMESTIC MARITIME ACADEMIES}

China's maritime educational level is complete, which formed the rather complete system composed of the formation of

- doctorate, master's degree,

- undergraduate (4 years),

- $\quad$ specialist (3 years)

- vocational and technical education.

- In which, there are 5 maritime universities

- Dalian Maritime University

- Shanghai Maritime University

- JiMei University (navigation institute and marine engineering)

- Wuhan University of Technology (marine and inland river)

- Ningbo University Maritime College;

- there are junior colleges like
- Zhejiang Institute of Communications

- Nantong Shipping College

There are more than 20 secondary vocational technical schools or shipping school locating at coastal provinces. Domestic maritime education is a comprehensive university with multi-subjects coordinated development in general, covering the disciplines of science, engineering, arts and management, with the characteristics of maritime transport, to explore the training mode of diversified compound talents. [1]

\section{A. Training Mode}

Postgraduate training in domestic maritime academies is mainly by the way of establishment of graduate faculty responsible for all the professional postgraduate program development and the specific training content is formulated by each secondary college. Each college has the right to arrange the teaching of the course and the training assessment of the teaching ability and practical skills, and the school retains the power of the management of postgraduate public courses, specialized courses, optional courses, scientific research funds and the right of declaration and evaluation of scientific research achievements, and determines each student's tutor through a two-way selection. The preceptor tutor gives professional guidance to students in his research field, widens students' scope of knowledge, trains their research ability, and instructs them to complete the graduation thesis. At the same time, the domestic maritime colleges are intensifying cooperation with the enterprises, and strive to establish a production, study, research alliance, forming the training mode of combination of theory and practice.

\section{B. Curricula Setting}

The general curriculum of higher maritime education in China is mainly divided into public compulsory course, professional degree course and optional course, making a feature of shipping, forms the specialized curriculum system with multi-disciplinary interdisciplinary development. The current postgraduate training model is mainly divided into two types, master's degree and doctor degree, each of which is independently cultivated, with study duration of more than 2 years for master's degree, and 3 years for doctoral degree. The early stage is of the study of public compulsory course, professional degree course and optional course, and the latter 
is for the embarkation or the shipping related enterprise practice and to complete the dissertation.

\section{Experiment and Practice}

The goal of postgraduate training in maritime academies is to train the compound high-level talents engaged in the practical work of maritime or related enterprises according to the specific professional needs. Take Dalian Maritime University for example, it starts from two aspects:

- The basic facilities for the first, the school built a fully functional navigation professional teaching laboratory, navigation training and research center, water survival training hall. With more than 40 teaching and research laboratories such as navigation simulation laboratory, marine simulation laboratory, etc. and 2 ocean teaching practice ships.

- The practice for the second, to carry out various models of practical training and absorb the enterprise practice projects. At the same time, the academies cooperate with a number of large-scale enterprises having strong internal needs and research and development capacity, improve the graduate student's scientific research ability, innovation ability and work ability, laying the foundation for the future work position. [2]

\section{Teaching Form and Administrative Situation}

Regarding the teaching form, the postgraduate tutor mainly helps the students to make the plan during the study period, and carries on the follow-up instruction, enhances the theoretical level of specialized research and the research ability. Meanwhile, the academies also regularly invite professionals and business experts to open lectures for broadening the horizons of students.

Regarding the management, with the expansion of postgraduate enrollment in China's maritime academies in recent years, big difference appeared in the age of the students, structure, professional background, personal experience and so on. Therefore, in addition to the direct management of the graduate departments of the academies, it also sets up specialized postgraduate counselors and teaching secretaries to help students solve various difficulties and problems in life, study and thought for relieving their worries. [3]

\section{Postgraduate Training Mode OF Foreign MARITIME ACADEMIES}

\section{A. Postgraduate Training Mode of European and American Maritime Academies}

The postgraduate training mode of European and American maritime academies has undergone a century of mutual reference and development, that forming a contemporary American postgraduate training mode, the teaching postgraduate training mode (see "Table I").

TABle I. Teaching Postgraduate Training Mode of European And American Maritime ACADEMIES

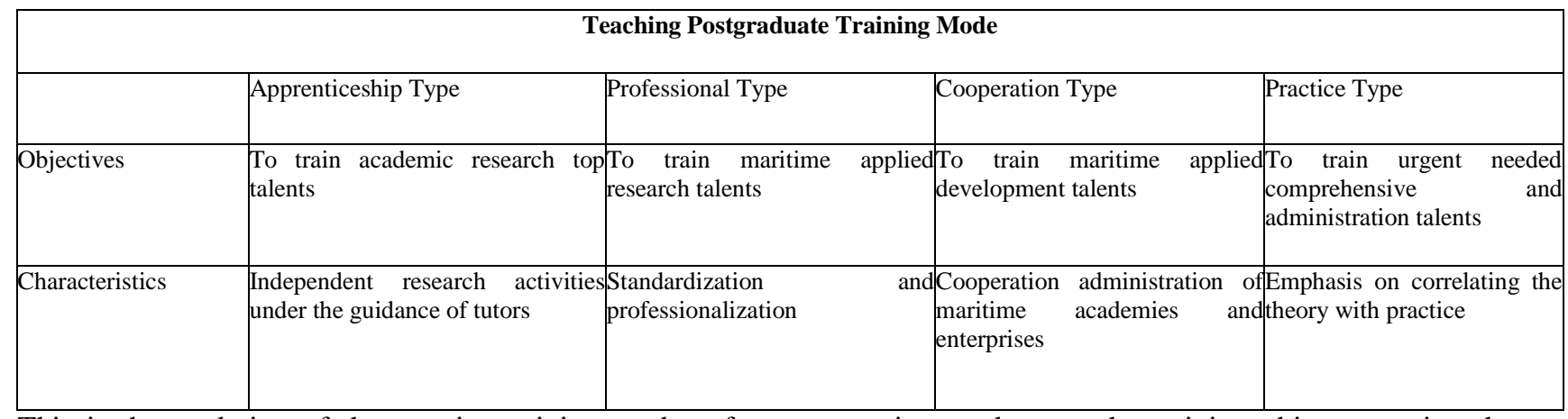

This is the evolution of three major training modes of apprenticeship, professional and cooperation. Among them, the mode of apprenticeship postgraduate training, represented by the German education of postgraduates with the training goal of developing the academic research top talents, later became the mode of professional postgraduate training in maritime academies, which was represented by the United States, aiming at cultivating maritime applied research talents. After World War II, due to the development of science and technology, it forms the cooperation postgraduate training mode as the goal of training maritime applied development talents. Then, on the basis of the early three kinds of postgraduate training modes, it forms the practical postgraduate training mode which takes the actual marine workers as the training objects, serving the urgent needed comprehensive and management talents in the port and shipping enterprises. [4]

\section{B. Current Situation of Postgraduate Training of Japanese and Korean Maritime Academies}

The development and change of maritime academies in Japan and Republic of Korea are similar, and the mode of postgraduate education is gradually formed on the basis of reference to the training mode of postgraduates in the Great Britain, the United States and Germany (see “Table II"). 
TABLE II.

CURRENT Situation of PostgraduAte Training of JaPANeSE AND Korean Maritime ACADEMIES

\begin{tabular}{|l|l|l|l|}
\hline \multicolumn{3}{|c|}{ Teaching Postgraduate Training Mode } \\
\hline & Training Process & Double Tutors & Training Goal \\
\hline Characteristics & $\begin{array}{l}\text { Focus on unity of teaching norms } \\
\text { and scientific research }\end{array}$ & $\begin{array}{l}\text { The professor mainly provides research topics and Enable graduate students to have } \\
\text { plans, supervises, directs and implements them; Theindependent thinking, analysis and } \\
\text { Associate professor is responsible for the specificproblem solving skills } \\
\text { implementation of each subject }\end{array}$ \\
\hline
\end{tabular}

Putting emphasis on the unity of teaching norms, science and scientific research in the training process, and its organizational administration is a specialized administration institution, which is based on the graduate school, with the hierarchical organizational structure. In the process of postgraduate training, it implements the system of double tutor training. The professor mainly provides research topics and plans, supervises, directs, implements and strengthens the internal and external links, while the Associate Professor is responsible for the specific implementation of various topics, in addition to teaching, often engages in scientific research with students. [5]

\section{COMPARISON OF TRAINING AND MANAGEMENT OF POSTGRADUATE TRAINING BETWEEN DOMESTIC MARITIME ACADEMIES AND FOREIGN ACADEMIES}

\section{A. Comparison of Specialties and Curricula}

Foreign maritime postgraduate professional setting is professional and targeted, establishing its own system. It has practical guiding significance for students to embark on a society, enables students to quickly integrate into the enterprise work. Domestic maritime academies have a wide range of professional settings, including

- engineering

- Science

- Arts

- Management

- other multidisciplinary disciplines

Compared with foreign maritime academies, the domestic maritime academy is a comprehensive university covering various disciplines. Although not as specific as the professional and curriculum of foreign maritime academies, it is a complementary for students to master more comprehensive knowledge, in line with the characteristics of the needs of the domestic market. particularly, it is more unique to deal with international cities and strengthen the comprehensive talent needs of high-end shipping services field.[6]

\section{B. Comparison of Educational Administration System}

The department system for administration is widely used in American universities, and the graduate work is mainly in charge of departments. The teaching institution setting of Japanese Kobe University of Mercantile Marine is very concise, convenient and efficient that students can talk directly with the teachers. While the administration system of domestic maritime academies is relatively cumbersome, that students sometimes do not know which department to consult. Foreign maritime academies have perfect student self-government system. Using Kobe University of Mercantile Marine as an example, it establishes the student government, although similar with the form of Chinese college students union, the student government manages all the students affairs; the university only supervises and guides the student government but not participating in the specific affairs. (7)

Although the domestic maritime academies set up graduate students union, due to the power of management and operation is mainly concentrated in the hands of students affairs department set up by the school, the management and operation mechanism is inflexible, which leads to the low participation postgraduates and self-government degree.

\section{Comparison of Training Mode}

At present, the training mode of postgraduate in domestic maritime academies is divided into full-time postgraduates and on-job postgraduates according to the way of study, the former mode accounts for a large proportion of the total postgraduate enrollment and the latter one accounts for a relatively small proportion; While the proportion of foreign on-job postgraduates is comparatively high. Domestic and Japanese and Korean maritime academies graduate education take "strict entry and easy exit" as characteristics, it is difficult to enter the schools but easy to graduate. European and American academies adopt the system of "easy entry and strict exit", with high natural selection rate. For the two systems each has its merits. For master students, the domestic maritime academies pay attention to theoretical study, while foreign academies focus on the combination of theory and practice; for doctoral students, domestic and foreign academies are almost the same focused on academic research.

\section{Comparison of Practice and Internship}

The domestic maritime academies focus more on the study of theoretical knowledge, but not on practice and internship. Dalian Maritime University, although it has an internship ship and provides internship opportunities and places, still cannot meet the needs of practice for students in maritime academies. Owing to the limitation of funds, it is difficult to compare with the developed countries in the quantity, frequency and the advancement of navigational teaching equipment. A major feature of maritime colleges in the World Maritime University is the professional practice system. Each student has 5 or 6 internship opportunities, and the school also arranges a lot of time and opportunity to go 
deep into the shipping enterprises, ports and government departments that are related to their majors. [5]

\section{REFERENCE AND IMPROVEMENT}

\section{A. Training Goal}

European and American maritime academies aim at cultivating compound talents, which is the demand of economic globalization and world integration, with certain innovativeness and progressiveness. In order to meet the needs of the profession and the requirements of the Times, the domestic maritime academies should be based on their own situation and targeted at training talents of high level compound amphibious port and shipping. On the one hand to adhere to the characteristics of navigation professional training, on the other hand to increase the infiltration of shipping features of navigational academies to the nonnavigational specialties, so as to establish a multidisciplinary, multidisciplinary, multi-level comprehensive talent training base around the shipping industry. The training goal involves two aspects.

- To train high-quality shipping professionals

- To train shipping-related high-end service personnel, highlighting professional characteristics.

\section{B. Curricula Setting}

The curriculum setting should conform to the development of today's society and the needs of enterprises, and combine the theory with practice. Foreign maritime academies attach great importance to practice and cultivate critical thinking of students, which is worth learning from. It is not conducive to cultivate students ' pioneering and innovative spirit and independent thinking ability for the traditional emphasis on theory but not practice in Chinese academies. There is still a gap between the curriculums and the social development and demand in China's maritime academies, so we should increase the proportion of practical courses, widen the subject range of postgraduate curriculum, increase the number of optional courses, and keep up with the pace of social development and times demand.

\section{Training Mode}

A notable feature of the postgraduate training mode in Europe, America, Japan and Korea is to give full play to interest to exercise their ability which is to analyze and solve problems. We shall change the current situation of the single training mode of maritime academies, form open training mode to cultivate students ' independence and creativity. Maritime academies should adjust the training plan according to the different requirements of market and enterprise in different periods. Not only to pay attention to the self-cultivation, but also to strengthen the students joined with enterprises, carry out a variety of modes of practical teaching, to create an emulational enterprise practice environment, to absorb the enterprise practice projects, and to strengthen the graduate innovative application ability.

\section{Management Method}

To learn from the European and American academies management model, simplify the teaching management mechanism, adhere to the combination of school management and graduate students' own construction, and create a new idea of postgraduate management in maritime academies with Chinese characteristics. Learning from the management of maritime academies, we should

- Perfect the postgraduate enrollment and training management mechanism

- Perfect the development plan of postgraduate education and the system of tutor team construction.

- This methods are to

- Form a lean efficient and optimized management system and a good operating system.

- To grasp the management of postgraduates

- To improve their ability of self-education, selfmanagement and self-discipline.

\section{CONCLUSION}

In conclusion, there are many differences in the postgraduate education between maritime academies at home and abroad, which has a large gap in our country compared with that of foreign countries in many aspects.

In the author's point of view,

- We should take a positive view of foreign maritime academies postgraduate training mode, and find a new way not only meets the actual situation of domestic maritime academies but also enables to cultivate high-end shipping talents.

- We should strengthen the reform of postgraduate education system and improve the way of training, so that the postgraduate education in maritime academies can develop faster and better.

\section{REFERENCES}

[1] Wu, Y. (2001). Research on Students Management of World-class Higher Maritime Education Institutions. Maritime Education and Research, 6(2), 4-6.

[2] Shi, Y. (1989). History of Dalian Marine College. Dalian: Dalian Marine College Press.

[3] Science and Education Department, Ministry of Transport. (2003) Research Report on current situation of Chinese Maritime Education and Training.

[4] Wu, Z. (1993). Research Report on Maritime Academies of US Maritime Education and Research, 3(1-2).

[5] IMO. (2001). STCW convention and STCW code. London: Author.

[6] Introduction of World Maritime University [EB/OL]. (2008-1-21). http://

www.eedu.com.cn/News/ruidianliuxue/HTML/shijiehaishidaxuegezh uanye.html.

[7] Wu A. (2004). Comparison of Postgraduate Education Between Japan and China. Postgraduate Education, (17):12. 
[8] BIMCO/ ISF (2000). Manpower update: the world-wide demand for and supply of seafarers: main report. Warwick: Institute for Employment Research. 